Bulletin UASVM Food Science and Technology 70(1)/2013, 33-37

ISSN-L 2344-2344; Print ISSN 2344-2344; Electronic ISSN 2344-5300

\title{
Safety Evaluation of the Grape Marc Spirit by GC-FID Analysis
}

\author{
Teodora Emilia COLDEA ${ }^{1)}$, Elena MUDURA ${ }^{* 1)}$, Nicoleta RANTA ${ }^{2)}$, Darius \\ HADAREAN ${ }^{1)}$ \\ ${ }^{1)}$ Faculty of Food Science and Technology, University of Agricultural Sciences and Veterinary \\ Medicine, 400372, Cluj-Napoca, Romania \\ ${ }^{2)}$ Physical and Chemical Testing Laboratory SC Prodvinalco SA, 400230, Cluj-Napoca, Romania \\ *elena.mudura@usamvcluj.ro
}

\begin{abstract}
There were investigated grape marc spirits regarding their safety on consumers. Major volatile compounds which present risk to human health (such as methanol, furfural, and acetaldehyde) and ethyl alcohol content were compared to European Union Regulation and other values found in previous studies. The aim of our study was to evaluate the safety of grape marc spirits considering their content in major volatile compounds by comparison with the requirements of European Union Regulation. We investigated the ethyl alcohol content by electronic densimetry and 10 major volatile compounds (acetaldehyde, ethyl acetate, methanol, 1-propanol, 1-butanol, 2-butanol, isobutyl alcohol, isoamyl alcohol, amyl active alcohol and furfural) by Gas Chromatography coupled with Flame Ionization Detector. We used reference chemicals to identify these compounds and 3-pentanol as internal standard to quantify the volatiles. Results were compared with the requirements of European Union Regulation. All major volatile compounds registered values in accordance to EU Regulation and the grape pomace spirits samples do not present any kind of risk for consumption.
\end{abstract}

Keywords: grape marc spirit, food safety, methanol, furfural, acetaldehyde.

\section{INTRODUCTION}

The consumption of unrecorded alcohol is a worldwide issue, with impact on consumers' health. Unrecorded alcohol includes any kind of alcohol which is not taxed as alcoholic beverage, such as illegally produced or commercialized alcohols products. The technological process for producing alcohol should be conducted by qualified personnel who have the necessary experience to obtain a safe beverage for consumers.

All alcoholic beverages produced around the world must be considered by the authorities because the resulting product components can present a real risk. In EU countries it is reglemented by law the most harmful components found in alcoholic beverages and many studies evaluated these components (Quesada Granados et al., 1996, Geroyiannaki et al., 2007, Versini et al., 2009, Cortés et al., 2010, Lukić et al., 2011).

Our previous researches were conducted to verify the safety of these drinks on humans regarding their content in organochlorine pesticides, heavy metals, toxic volatile compounds and microbial contamination (Rusu et al., 2010, 2011, Coldea et al., 2012, Rotar et al., 2012).

While not as popular in Romania as fruit brandies, such as plum, pear or apple brandies, grape marc spirit is gaining ground because of the revaluation of waste from the winemaking industry. Being more popular in Mediteranean countries, studies had been developed on eau-de-vie de marc (French grape marc spirit), the Italian grappa, tsipouro (from Greece) or zivania from Cyprus (Danilatos and Harvala, 1981, Apostolopoulou et al., 2005, Geroyiannaki et al., 2007). The Reg. 110/2008 of EU established the general production methologies and analytical parameters for each type of alcoholic beverage. Grape marc spirit 
is produced exclusively from grape marc. Distillation is conducted to an alcoholic strength between 37.5 and $86 \%$ vol. Redistillation is permitted at the same range. No added alcohol or flavorings is permitted. Some of the major volatile compounds found in fruit spirits can have harmful effects on our health. Methanol, furfural and acetaldehyde can have toxic effect to the human organism when ingested in large amounts, which is why European Commission established the maximum admissible value for methanol to be $1000 \mathrm{mg} \% \mathrm{~mL}$ pure alcohol (p.a.). Furfural it is regulated by law to a maximum content of $2 \mathrm{mg} \% \mathrm{~mL}$ p.a. Volatile substances must exceed $140 \mathrm{mg} \% \mathrm{~mL}$ p.a. Acetaldehyde represents the main aldehyde present in fruit spirits. Beyond the factors of their appearance in the final spirit drink might be fermentation temperature, the amount of $\mathrm{SO}_{2}$ in marc or the oxidation of ethanol by acetic acid bacteria in the presence of oxygen. Methanol is formed during the grape processing and fermentation by the hydrolytic demethoxylation of esterified methoxyl groups of the pectin in the presence of pectic enzymes (Lukić et al., 2011). Furfural can be formed during distillation by hydrolysis of acids or by heating the unfermented pentose and Maillard reactions. Other studies presented as a cause of furfural occurrence to be the aging process of the distillates (Quesada Granados et al., 1996).

\section{MATERIALS AND METHODS}

\section{Provenience of samples}

The grape marc spirits produced in USAMV Cluj-Napoca pilot station were evaluated for the presence of contaminants with risk for consumption. After having pressed the grapes in the winemaking process, the grape pomace is fermented. The volatile components thus formed are then recovered by distillation after in stills made of copper. The distillation process is selected, as two sequential cuts of distillate, a first cut to separate the head products from the heart products, and a second cut to separate the heart products from the tail products. The head fraction, or the first fraction of condensate, is very rich in methanol; the heart fraction, or the second fraction of condensate is a complex mixture of volatiles, most of which contribute to sensorial characteristic (G1); the tail fraction, or the last fraction of condensate is rich in less volatile compounds. The heart fraction is redistilled for separation of toxic volatile compounds (G2). The distillates were collected in two bottles and stored at $4^{\circ} \mathrm{C}$ before analysis.

\section{Alcohol concentration and the relative density}

The alcohol content and relative density analyses were made by the electronic densitometer type DDM2911, with digital display and measuring cell connected to an incorporated temperature regulator, made by Rudolf Research Analytical, series: 2045, measuring domain: $0-3 \mathrm{~g} / \mathrm{cm}^{3}$. The measurement result was an average of five values obtained for alcohol concentration and respectively, for the relative density. The density was displayed with 5 decimals and alcoholic concentration with 2 decimals.

\section{Volatile compounds analysis}

Analysis of major volatile compounds of the two fractions of distillate was adapted after the EU reference method for volatile compounds found in alcoholic beverages. For the determinations of the major volatile compounds, the samples were injected directly into the gas chromatograph column, from a GC-FID Agilent Tehnologies gas chromatograph, 6850A, without preliminary treatment. Each sample was injected twice in the GC-FID. One micro liter from each sample was introduced in the capillary chromatography column ZB-WAX plus (characteristics: $60 \mathrm{~m}$ length, $0.25 \mathrm{~mm}$ diameter, $0.25 \mu \mathrm{m}$ film thickness, stationary phase: 
cross linked polyethylene glycol) produced by Zebron Company. Inside the oven, the initial temperature was $35^{\circ} \mathrm{C}$. The injector temperature was $240^{\circ} \mathrm{C}$, automatic injection. The carrier gas was Helium. Detector (FID) temperature was $250{ }^{\circ} \mathrm{C}$ (Rusu et al., 2011). The temperature program is represented in Tab.1. The total analysis time of each sample was $30.63 \mathrm{~min}$.

Tab.1

Temperature program used for the GC-FID analysis of grape spirits

\begin{tabular}{|c|c|c|c|}
\hline Ramps & Rate & Final temperature & Final time \\
\hline 1 & $12^{\circ} \mathrm{C} / \mathrm{min}$ & $35-58^{\circ} \mathrm{C}$ & $4 \mathrm{~min}$ \\
\hline 2 & $3^{\circ} \mathrm{C} / \mathrm{min}$ & $58-85^{\circ} \mathrm{C}$ & $0 \mathrm{~min}$ \\
\hline 3 & $30^{\circ} \mathrm{C} / \mathrm{min}$ & $155^{\circ} \mathrm{C}$ & $3 \mathrm{~min}$ \\
\hline 4 & $200^{\circ} \mathrm{C} / \mathrm{min}$ & $230^{\circ} \mathrm{C}$ & $5 \mathrm{~min}$ \\
\hline
\end{tabular}

The main components (methanol, acetaldehyde, ethyl acetate, 1-propanol, 2-butanol, 2-methyl-1-propanol, 3-methyl-1-butanol, 2-methyl-1-butanol, 1-butanol, furfural), were identified by comparing their retention times with those of authentic compounds (see Chemicals and reagents). For quantitative evaluation it was applied the internal standard method, with a known amount of 3-pentanol, as internal standard (IS). As such, a solution containing $0.1 \mathrm{~mL} 3$-pentanol was added to $10 \mathrm{~mL}$ of every each sample. For all volatiles, the quantitative evaluation was based on automatic calculation, based on peak area integration, while for furfural the integration was done, manually.

\section{Chemicals and reagents}

All used chemicals (ethanol, acetaldehyde, methanol, propanol, 1-butanol, 2-butanol, 2-methyl-1-propanol, 3-methyl-1-butanol, 2-methyl-1-butanol, ethyl acetate, 3-pentanol, furfural) with purity over $99 \%$ were purchased from Merck and Sigma Aldrich Company.

\section{Statistical analysis}

The results obtained from the individual experiments were used to calculate the mean values and standard deviation values for the two apple brandy fractions samples.

\section{RESULTS AND DISCUSSIONS}

\section{Alcohol concentration based on relative density determination}

The values obtained for alcohol concentration based on relative density measurement were for G1 and G2, 36.16\%v/v, and $39.85 \% \mathrm{v} / \mathrm{v}$ respectively, which are in accordance with previous studies (Apostolopoulou et al., 2005).

\section{GC-FID analysis}

There were identified the main volatile compounds by their retention times and by comparison with pure standards. The internal standard used in all cases was 3-pentanol. Based on the peak areas, for each sample it was calculated the concentration of each component, expressed as $\mathrm{mg} \% \mathrm{~mL}$ p.a. The individual and mean values for each volatile found in the samples resulted from the distillation process were compared with those reglemented by the EU legislation and by comparison with other references (Tab. 2). 
Major volatile compounds identified in the samples collected from the two distillation stages (G1, G2) in comparison with other references

\begin{tabular}{|c|c|c|c|c|}
\hline \multirow{2}{*}{$\begin{array}{l}\text { Volatile compound, } \\
\text { mg\% mL p.a. }\end{array}$} & \multirow{2}{*}{$\begin{array}{c}\mathrm{G} 1 \\
\left( \pm \mathrm{SD}^{*}\right)\end{array}$} & \multirow{2}{*}{$\begin{array}{c}\mathrm{G} 2 \\
( \pm \mathrm{SD})\end{array}$} & \multicolumn{2}{|c|}{ References } \\
\hline & & & Different fruit brandies & Grape marc spirit \\
\hline Acetaldehyde & $\begin{array}{c}45.57 \\
( \pm 0.06)\end{array}$ & $\begin{array}{c}30.96 \\
( \pm 0.03)\end{array}$ & $\begin{array}{c}1.3-59.7^{(1} ; 7.4-31.0^{(2} ; \\
14.49-19.92^{(3} ;\end{array}$ & $\begin{array}{l}20.3-53.7^{(5} ; 51.7-76.71^{(6} ; \\
1.57-51.1^{(7)} ; 21.4-29.9^{(8}\end{array}$ \\
\hline Ethyl acetate & $\begin{array}{l}1625.15 \\
( \pm 0.93)\end{array}$ & $\begin{array}{l}1037.79 \\
( \pm 4.02)\end{array}$ & $\begin{array}{l}7.6-692.1^{(1} ; 150.5-376.8^{(2} ; \\
17-128^{(4} ; 246.04-312.62^{(3}\end{array}$ & $\begin{array}{c}73.8-166.91^{(6} ; 21.5-69.2^{(7} \\
26.3-51.7^{(8}\end{array}$ \\
\hline Methanol & $\begin{array}{l}739.98 \\
( \pm 5.79)\end{array}$ & $\begin{array}{l}658.28 \\
( \pm 1.09)\end{array}$ & $\begin{array}{l}93.2-1205.3^{(1} ; 346.4-895.1 \\
\quad{ }^{(2} ; 540.0-1140.0^{(4}\end{array}$ & $\begin{array}{c}165.7-955.8^{(5} ; 576.9-791.7 \\
{ }^{6} ; 136.0-340.6_{(8}^{(7} ; 85.0-454.3\end{array}$ \\
\hline Furfural & 0.00 & 0.00 & $0.93-6.23^{(4} ; 2.68-3.66^{(3}$ & $0.0-1.67^{(7} ; 0.04-0.37^{8}$ \\
\hline 2-Butanol & $\begin{array}{c}0.69 \\
( \pm 0.00)\end{array}$ & $\begin{array}{c}0.78 \\
( \pm 0.01)\end{array}$ & $0.6-171.5^{(1}$ & $\begin{array}{c}0.36-6.9^{(6} ; 0.0-40.9^{(7} ; 0.0- \\
0.2^{(8}\end{array}$ \\
\hline 1-Propanol & $\begin{array}{c}31.03 \\
( \pm 0.17) \\
\end{array}$ & $\begin{array}{c}32.93 \\
( \pm 0.02) \\
\end{array}$ & $\begin{array}{c}12.1-706.8^{(1} ; 65.6-186.8^{(2} \\
15.0-73.0^{(4}\end{array}$ & $\begin{array}{c}43.91-69.71^{(6} ; 12.3-32.3^{(7} \\
9.15-40.6^{(8}\end{array}$ \\
\hline 2-methyl-1-propanol & $\begin{array}{c}79.78 \\
( \pm 0.23)\end{array}$ & $\begin{array}{c}88.95 \\
( \pm 0.15)\end{array}$ & $\begin{array}{c}11.3-195.5^{(1} ; 40.6-110.0^{(2} \\
30.0-135.0^{(4}\end{array}$ & $62.61-87.79^{(6} ; 13.0-35.2^{(7}$ \\
\hline 1-Butanol & $\begin{array}{c}2.41 \\
( \pm 0.02)\end{array}$ & $\begin{array}{c}2.68 \\
( \pm 0.01)\end{array}$ & $\begin{array}{c}0.5-51.6^{(1} ; 3.0-33.5^{(2} ; 6.3- \\
116.0^{(4}\end{array}$ & $\begin{array}{c}1.55-3.13^{(6} ; 0.25-1.5^{(7} ; 0.5- \\
0.8^{(8}\end{array}$ \\
\hline 2-methyl-1-butanol & $\begin{array}{c}34.02 \\
( \pm 0.17) \\
\end{array}$ & $\begin{array}{c}39.43 \\
( \pm 0.07) \\
\end{array}$ & $11.0-81.8^{(1} ; 42.0-96.5^{(4}$ & $42.7-57.9^{(6} ; 20-28.1^{(7}$ \\
\hline 3-methyl-1-butanol & $\begin{array}{l}129.57 \\
( \pm 0.43)\end{array}$ & $\begin{array}{l}148.67 \\
( \pm 0.03)\end{array}$ & $58.9-422.5^{(1} ; 129.0-359.0^{(4}$ & $\begin{array}{c}118.5-200.7^{(6} ; 25.4-104.9^{(7} ; \\
79.6-159.4^{(8}\end{array}$ \\
\hline
\end{tabular}

*standard deviation; (1 - Winterová et al., 2008; (2 - Satora and Tuszynski, 2008; (3 - Rusu et al., 2011; (4 - Versini et al., 2009; (5 - Geroyiannaki et al., 2007; (6 - López-Vázquez et al., 2010; (7 - Cortés et al., 2010; $(8$ - Lukić et al., 2011

Acetaldehyde and higher alcohols registered values in accordance with fruit brandies and other grape marc spirits evaluated in presented references. With higher boiling points than ethanol, 3-methyl-1-butanol and 1-propanol are found in tails fraction (Claus and Berglund, 2005). Among higher alcohols only 2-methyl-1-propanol had similar values with fruit brandies but higher compared to other grape marc spirits (Satora and Tuszynski, 2008, Winterová et al. , 2008, Versini et al., 2009, Cortés et al., 2010, López-Vázquez et al., 2010). Ethyl acetate and methanol registered substantially higher values then fruit and grape marc spirits, maybe due to the not sufficient separation of the fractions in the distillation process. Still, no compound was found to be out of the values admitted by legislation (Reg. 110/2008).

\section{CONCLUSION}

The major volatile compounds found in two distillate fractions collected from the double distillation process of grape marc spirit were evaluated from the safety to consumers' point of view. Ethanol content evaluated by electronic densimetry and volatile compounds determined by GC-FID analysis, presented similar values to other references and no volatile compound was found to be out of the regulation value.

\section{REFERENCES}

1. Apostolopoulou A.A., A.I. Flouros, P.G. Demertzis and K. Akrida-Demertzi (2005). Differences in concentration of principal volatile constituents in traditional Greek distillates. Food Control 16: 157-164. 
2. Claus M. and K. Berglund (2005). Fruit brandy production by batch column distillation with reflux. J. Food Process Eng. 28(1):53-67.

3. Coldea T.E., C. Socaciu, M. Tofana, E. Vekony and N. Ranta (2012). Impact of distillation process on the major volatile compounds as determined by GC-FID analysis in apple brandy originated from Transylvania, Romania. Bulletin UASVM Agriculture. 69(2):228-235.

4. Cortés S., J.M. Salgado, N. Rodríguez and J.M. Domínguez (2010). The storage of grape marc: Limiting factor in the quality of the distillate. Food Control 21(11):1545-1549.

5. Danilatos N. and A. Harvala (1981). Evaluation of wine distillates Greek grape varieties. Greek Enological Chronicles 1, Athens, 88-93.

6. Geroyiannaki M., M.E. Komaitis, D.E. Stavrakas, M. Polysiou, P.E. Athanasopoulos and M. Spanos (2007). Evaluation of acetaldehyde and methanol in Greek traditional alcoholic beverages from varietal fermented grape pomaces (Vitis vinifera L.). Food Control 18:988-995.

7. López-Vázquez C., M.H. Bollaín, K. Berstsch and I. Orriols (2010). Fast determination of principal volatile compounds in distilled spirits. Food Control 21:1436-1441.

8. Lukić, I., Tomas, S., Miličević, B., Radeka, S. and Peršurić, Đ. (2011). Behaviour of volatile compounds during traditional alembic distillation of fermented Muscat Blanc and Muškat Ruža Porečki grape marcs. J. I. Brewing. 117:440-450.

9. Rotar M., C.A. Semeniuc, E. Mudura, T. Coldea and C. Lazar Pop (2012). Identification of Microbial Contamination Sources in Distilled Spirits. Bulletin UASVM Agriculture. 69(2):380-385.

10.Quesada Granados J., M. Villalón Mir, H. López García-Serrana and M.C. López Martínez (1996). Influence of aging factors on the furanic aldehyde contents of matured brandies: aging markers. J. Agric. Food Chem. 44:1378-1381.

11.Regulation (EC) No 110/2008 of the European Parliament and of the Council of 15 January 2008 on the definition, description, presentation, labelling and the protection of geographical indications of spirit drinks and repealing Council Regulation (EEC) No 1576/89. Official Journal of the European Union, 51, L39, 16-54.

12.Rusu (Coldea) T.E., C. Socaciu, C. Parau and A.A. Mocan (2010). Quality and safety analysis for some traditional homemade fruit distillates from Transylvania (North West Romania). Bulletin USAMV-CN. 67(2):395-403.

13.Rusu (Coldea) T.E., C. Socaciu, M. Pârv and D. Vodnar (2011). Gas-Chromatographic analysis of major volatile compounds found in traditional fruit brandies from Transylvania, Romania. Not. Bot. Horti. Agrobo. 39(2):109-116.

14. Satora P. and T. Tuszynski (2008). Chemical characteristics of Śliwowica Łącka and other plum brandies. J. Sci. Food Agric. 88:167-174.

15.Versini G., M.A. Franco, S. Moser, P. Barchetti and G. Manca (2009). Characterisation of apple distillates from native varieties of Sardinia island and comparison with other Italian products. Food Chem. 113:1176-1183.

16.Winterová R., R. Mikulíková, J. Mazáč and P. Havelec (2008). Assessment of the authenticity of fruit spirits by gas chromatography and stable isotope ratio analyses. Czech J. Food Sci. 26(5):368-375. 